\title{
WATER QUALITY AND DIVERSITY OF YEASTS FROM TROPICAL LAKES AND RIVERS FROM THE RIO DOCE BASIN IN SOUTHEASTERN BRAZIL
}

\author{
Adriana O. Medeiros ${ }^{1 *}$, Beatriz S. Missagia ${ }^{2}$, Luciana R. Brandão ${ }^{2}$, Marcos Callisto ${ }^{3}$, Francisco A. R. Barbosa ${ }^{3}$, Carlos A. \\ Rosa $^{2}$
}

${ }^{1}$ Departamento de Botânica, Instituto de Biologia, Universidade Federal da Bahia, Salvador, BA, Brasil; ${ }^{2}$ Departamento de Microbiologia, Instituto de Ciências Biológicas, Universidade Federal de Minas Gerais, Belo Horizonte, MG, Brasil; ${ }^{3}$ Departamento de Biologia Geral, Instituto de Ciências Biológicas, Universidade Federal de Minas Gerais, Belo Horizonte, MG, Brasil.

Submitted: July 12, 2011; Returned to authors for corrections: August 15, 2011; Approved: June 07, 2012.

\begin{abstract}
Yeast communities were assessed in 14 rivers and four lakes from the Doce River basin in Brazil, during the rainy and dry seasons of the years 2000 and 2001. Water samples were collected at the subsurface in all sites. The following physical and chemical parameters were measured: temperature, dissolved oxygen, $\mathrm{pH}$, electrical conductivity, total phosphorus, ortho-phosphate, ammonium, nitrate, nitrite and total nitrogen and the counts of faecal coliforms and heterotrophic bacteria were carried out to characterize the aquatic environmental sampled. The yeast counts were higher in aquatic environments with the highest counts of coliform and heterotrophic bacteria. These environments receive a high influx of domestic and industrial waste. A total of 317 isolates identified in forty eight yeast species were recorded in the sites sampled and the specie Aureobasidium pullulans were found in eleven out of eighteen sites sampled and some opportunistic pathogens such as the yeast species Candida krusei were isolated only in the polluted rivers with a positive correlation with the biotic and abiotic parameters that indicate sewage contamination.
\end{abstract}

Key words: tropical freshwater, yeast diversity and water quality

\section{INTRODUCTION}

Many bodies of water throughout the world are considered to be impacted by the input of allochthonous material from industrial and domestic effluents associated with human activities. These environments can host a great variety of microorganisms and may be considered a risk to human beings (9).
Yeasts are common inhabitants of aquatic environments and their density and species diversity depend on the water type and purity $(11,12)$. Despite this fact the knowledge of the ecology of freshwater yeasts is still incipient and present wide gaps related in particular to the factor that drive their distribution patterns, diversity and functional significance in aquatic systems (28).

Nevertheless, some researchers have proposed using the

*Corresponding Author. Mailing address: Departamento de Botânica, Instituto de Biologia, Universidade Federal da Bahia, Campus Universitário de Ondina, CEP: 40170-115, Salvador, Bahia, Brazil.; E-mail: adrianamedeiros@ufba.br 
presence of yeasts as an indicator of sewage contamination and recreational water quality as a complement to the coliform counts. Some studies have shown a correlation between the occurrence of yeasts in aquatic environments and the presence of fecal pollution indicators $(3,4,5,8,12,20)$. Yeasts populations respond quickly to organic contamination and some species could be used as indicators of nutrient enrichment in aquatic environments (5). Common yeast species isolated in freshwater have been associated with humans (20), and some of them are opportunistic pathogens such as the species Candida albicans, Candida parapsilosis, Candida krusei, Candida guilliermondii, Candida glabrata and Candida tropicalis.

The main objective of this study was to determine the levels of microbial water quality indicators and yeast species present in freshwater environments of the Doce River basin in
Brazil by sampling regions with different levels of anthropogenic impacts.

\section{MATERIALS AND METHODS}

\section{Study area}

This study was carried out in the Doce River basin, in the state of Minas Gerais in southeastern Brazil (Figure 1). The Doce River watershed is one of the most important basins in southeastern Brazil. The waters of the Doce River basin are used by more than 3 million inhabitants in approximately 300 municipalities. Rapid urbanisation has resulted in a lack of basic sanitation, resulting in degradation of the aquatic ecosystems of this region (18). Water samples were collected from two regions of the Doce River basin: Serra do Cipó and the Middle Doce River basin.

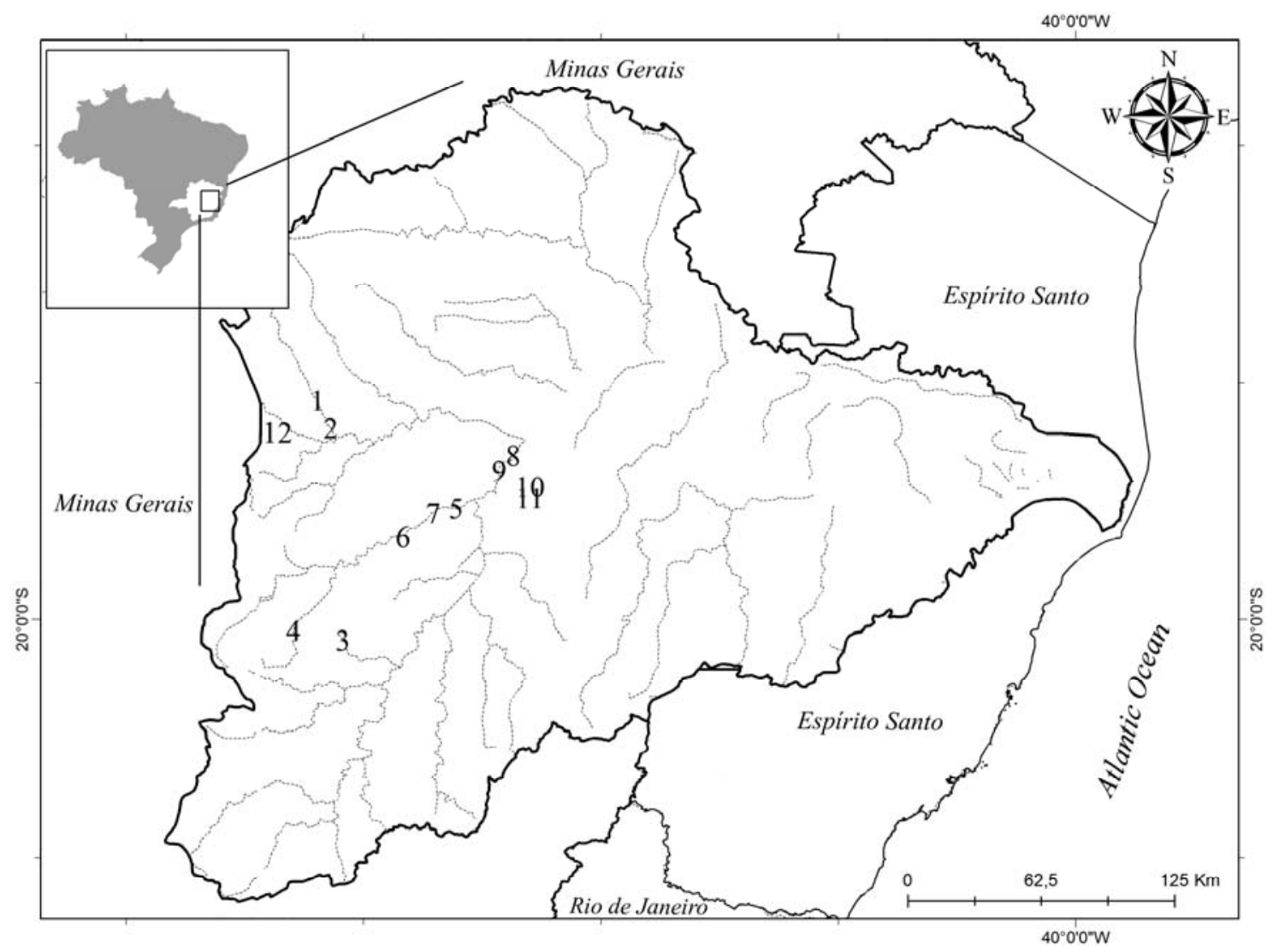

Figure 1. Location of the sampling stations (1-PEI1; 2-PEI2; 3-PER; 4 - SBR and CA; 5- PIR; 6- IPR; 7-SER; 8- DOL and CAL; 9-DOR; 10-ACL; 11-AML; 12-IND1, IND 2, IND 3 AND IND 4) in the middle Rio Doce basin, Minas Gerais State-Brazil 
Serra do Cipó is located in the central part of Minas Gerais State $\left(19^{\circ} 12^{\prime}-19^{\circ} 34^{\prime} \mathrm{S}, 43^{\circ} 27^{\prime}-43^{\circ} 38^{\prime} \mathrm{W}\right)$ and separates two important Brazilian watersheds: the São Francisco River basin and the Doce River basin. This region has a subtropical climate with a marked dry season, and the annual medium temperatures oscillate between $17^{\circ} \mathrm{C}$ and $19^{\circ} \mathrm{C}$ (7). In this region, a longitudinal gradient was studied and water sample was collection from five sites in the Indaiá stream, named IND1 ( $1^{\text {st }}$ order $), \operatorname{IND} 2\left(2^{\text {nd }}\right.$ order $), \operatorname{IND} 3\left(3^{\text {rd }}\right.$ order), IND4 ( $3^{\text {rd }}$ order) and IND5 ( $4^{\text {th }}$ order). A first order stream has no tributaries. When two first-order streams meet, they form a second-order stream, and so on (13). The IND sites are located inside the Serra do Cipó National Park, and these points are considered to be free of anthropogenic impacts. Samples were also collected from two sites in the Peixe river, named PEI1 and PEI2 ( $5^{\text {th }}$ and $6^{\text {th }}$ order stretches, respectively), that are located outside of the Serra do Cipó National Park and have been affected by humans (7).

The middle stretch of the Doce River basin is located in southeastern Brazil. This region also includes the Doce River State Park (ca. 36,000 ha), the largest remnant of the Atlantic Forest in the State of Minas Gerais and one of the few places in Brazil where non-impacted natural lakes can be found. The climate of this region is characterised by two well-defined seasons: a dry season from May to August/September and a rainy season from October to March (18). In this region, seven rivers were sampled representing the mainly sub-basin of the middle Rio Doce basin: the Caraça (CAR), Santa Bárbara (SBR), Peixe (PER), Severo (SER), Piracicaba (PIR), Ipanema (IPR) and Doce rivers (DOR). Four lakes from the region were also studied, two located in the Doce River State Park, Carioca Lake (CAL) and Dom Helvécio Lake (DOL); and the other two sites located outside of the park, in the region of the Eucalyptus reforestation area, Amarela Lake (AML) and Águas Claras Lake (ACL) (21).

\section{Sampling}

Sample collections and physical and chemical measurements were carried out in the rainy and dry periods in January and August, respectively, of both 2000 and 2001. Water samples were collected at the littoral zone of the rivers. In the lakes, the samples were collected in the limnetic zone in the sub-surface water column. The water samples for microbiological analysis were directly collected into sterilised bottles. The samples were transported to the laboratory on ice and the analyses were carried out within $8 \mathrm{~h}$ of sampling.

The water temperature, electric conductivity, $\mathrm{pH}$ and dissolved oxygen were measured in situ with a multi-probe analyser (Horiba, mod. U-22). At all of the sites, water samples were collected to determine the contents of total nitrogen, nitrate, nitrite (17), ammonium, total phosphorus and phosphate (10).

The quantification of faecal coliform bacteria was made by the standard most probable number (MPN) method according to Eaton et al. (9). Water samples were inoculated into lactose broth (Difco, USA) for the presumptive phase. If the water samples showed positive results in the presumptive phase, it was then inoculated into brilliant green lactose bile broth (Difco, USA) for total coliforms (TC) and EC broth (Difco, USA) to confirm the presence of faecal coliforms (incubated at $44.5^{\circ} \mathrm{C} \pm 0.2$ during $24 \mathrm{~h}$ ). The results were expressed as MPN per $100 \mathrm{~mL}$ of water sample. The enumeration of heterotrophic bacteria was performed utilising the pour plate method on NWRI agar incubated at $25^{\circ} \mathrm{C}$, for five days (9). For yeast isolation, $0.1 \mathrm{ml}$ aliquots of undiluted water samples were spread in triplicate on YMA (1\% glucose, $0.5 \%$ peptone, $0.3 \%$ malt extract, $0.3 \%$ yeast extract, $2.0 \%$ agar) supplemented with $200 \mathrm{mg}$ chloramphenicol $\mathrm{L}^{-1}$. The plates were incubated at room temperature $\left(25 \pm 3^{\circ} \mathrm{C}\right)$ during 5 days. Each different yeast morphotype was counted, purified, and maintained on $\mathrm{YM}$ slants or frozen at $-80^{\circ} \mathrm{C}$ for later identification. The yeasts were characterised by standard methods (30). Identifications followed the taxonomic keys of Kurtzman \& Fell (15). Yeasts isolates of uncertain identity were confirmed by sequencing the D1/D2 variable domains of the large subunit rDNA using the primers NL-1 (5'-GCATATC 
AATAAGCGGAGGAAAAG-3') and NL-4 (5'-GGTCCGTG TTTCAAGACGG-3'). The DNA extraction were done according to Brandão et al (6) and the D1/D2 variable domains of the large subunit of the $r$ RNA gene were amplified as described by Lachance et al (16). Sequencing of the D1/D2 domains was performed directly from purified PCR products using a MegaBaceTM 1000 automated sequencing system (Amersham Biosciences). The sequences obtained were compared with those included in the GenBank database using the BASIC LOCAL ALIGNMENT SEARCH TOOL (BLAST at http://www.ncbi.nlm.nih.gov) (1).

\section{Statistical Analyses}

To verify the significantly differences among the sites sampled (rivers $\mathrm{X}$ lakes), the years when the studies were conducted (2000 and 2001) and the period (dry and rainy) a PERMANOVA test was used with a software package PERMANOVA for PRIMER, 2006 (2). The Canonical Correspondence Analysis (CCA) was used to verify the main trend of distribution of yeast species in relation to the biotic and abiotic parameters. The biotic data were transformed in log $(x+1)$. For the CCA analyses were utilized the program CANOCO for Windows 4.5 (29).

\section{RESULTS}

\section{Physical and chemical parameters}

In all of the analysed sites, the highest temperatures were obtained during the rainy period. In Serra do Cipó, the temperature varied from $14^{\circ} \mathrm{C}$ to $23.5^{\circ} \mathrm{C}$ and in the middle of the Rio Doce basin, from $12.7^{\circ} \mathrm{C}$ to $29^{\circ} \mathrm{C}$. The $\mathrm{pH}$ values varied from 4.0 at the CAR site (rainy season of 2000) to 8.0 at the SBR site (rainy season of 2001). In Serra do Cipó, the sample sites showed acidic water during the rainy season $(\mathrm{pH}$ 4.2 - 5.7) and during the dry season the $\mathrm{pH}$ levels increased (pH 4.7 - 7.2). The conductivity values were highly variable during the sample years $(1 \mu \mathrm{S} / \mathrm{cm}$ to $375 \mu \mathrm{S} / \mathrm{cm})$ and were higher during the rainy season. The sites from Serra do Cipó had the lowest values for these parameters. The values for dissolved oxygen ranged from $0.3 \mathrm{mgL}^{-1}$ to $10.3 \mathrm{mg} \mathrm{L}^{-1}$, generally being higher during the dry season. In the rivers, the values of dissolved oxygen reached up to $5.6 \mathrm{mg} \mathrm{L}^{-1}$, except at the IPR site. In the lakes, the values of dissolved oxygen varied from 2.7 to $11.0 \mathrm{mg} \mathrm{L}^{-1}$. The values of total phosphorus ranged from $9.2 \mu \mathrm{g} \mathrm{L}^{-1}$ to $28 \mu \mathrm{g} \mathrm{L}^{-1}$ in the Serra do Cipó sample sites. In the rivers of the middle Doce River basin, the values ranged from $4.7 \mu \mathrm{g} / \mathrm{L}$ (CAR site - rainy season) to $843.3 \mu \mathrm{g} \mathrm{L} \mathrm{L}^{-1}$ (IPA site - dry season). Soluble reactive phosphorus values ranged from $1.2 \mu \mathrm{g} \mathrm{L} \mathrm{L}^{-1}$ to $455.5 \mu \mathrm{g} \mathrm{L}{ }^{-1}$, with the lowest values being found in the lakes. Total nitrogen ranged from $48.1 \mu \mathrm{g} \mathrm{L} \mathrm{L}^{-1}$ to $5,988.0 \mu \mathrm{g} \mathrm{L}^{-1}$ and the ammonium values ranged from $2.6 \mu \mathrm{g}$ $\mathrm{L}^{-1}$ to $3,320.0 \mu \mathrm{g} \mathrm{L}^{-1}$, with the highest values obtained at the IPR site. For all of the sites sampled, the values of nitrate ranged from 0.5 to $826.0 \mu \mathrm{g} \mathrm{L}^{-1}$, and those of nitrite ranged from $1.6 \mu \mathrm{g} \mathrm{L}^{-1}$ to $193.2 \mu \mathrm{g} \mathrm{L}^{-1}$. The majority of the sample sites in Serra do Cipó had values of ammonia and nitrite that were below the detection limits for the method used.

\section{Microbial parameters}

Table 1 show the results of coliform counts. In Serra do Cipó, the sites PEI1 and PEI2 showed the highest counts of coliforms (2,200 to 2,800 MPN $100 \mathrm{~mL}^{-1}$ of total coliforms and 500 to $700 \mathrm{MPN} 100 \mathrm{~mL}^{-1}$ of faecal coliforms, respectively) during all sampled periods, with even higher counts found during the rainy season of 2000. In the middle part of the Doce River basin, the coliform counts ranged from $<2$ MPN 100 $\mathrm{mL}^{-1}$ (CAR site) to $1,600,000 \mathrm{MPN} 100 \mathrm{~mL}^{-1}$ (IPR site). In the lakes, the coliform counts were high in the year 2000, with total coliform counts reaching up to $500 \mathrm{MPN} 100 \mathrm{~mL}^{-1}$ and faecal coliform counts reaching up to $330 \mathrm{MPN} 100 \mathrm{~mL}^{-1}$. The lowest counts of total and faecal coliform bacteria were found in Carioca Lake.

Yeasts were isolated in all sites sampled in Serra do Cipó, and the highest counts were found in the site PEI2 (420 cfu $\mathrm{mL}^{-1}$ ) (Figure 2: mean \pm standard error, $\mathrm{n}=3$ ). The number of heterotrophic bacteria in these sites ranged from $1.9 \times 10^{2}$ to 
$3.0 \times 10^{5} \mathrm{cfu} \mathrm{mL}^{-1}$, and the highest counts were found during the dry season. In the sample sites in the middle Doce River basin (Figure 3: mean \pm standard error, $\mathrm{n}=3$ ), the number of yeasts during all periods sampled ranged from 10 to $466 \mathrm{cfu} \mathrm{mL}^{-1}$. The highest counts of yeast were found in the sites SER (186 cfu $\mathrm{mL}^{-1}$ ), PIR (466 cfu $\mathrm{mL}^{-1}$ ) and IPR (383 $\mathrm{cfu} \mathrm{mL}^{-1}$ ) during the dry season of 2000. The sampled rivers in the middle of the Doce River basin had the highest counts of heterotrophic bacteria. In the lakes, the yeast counts ranged from 3.3 to $13.3 \mathrm{cfu} \mathrm{mL}^{-1}$. At Dom Helvécio Lake yeasts were found only in the rainy season of the sampled years. In Aguas Claras lake (ACL), yeasts ranged from 3.3 to $10 \mathrm{cfu} \mathrm{mL}^{-1}$ and were isolated in all sample dates. In Amarela Lake (AML) yeasts were isolated only during the dry season of 2000, counts of heterotrophic bacteria ranged from $1.0 \mathrm{x}$ $10^{3}$ to $3.0 \times 10^{5} \mathrm{cfu} \mathrm{mL}^{-1}$ and the highest counts were found during the rainy season of 2000 for all of the lakes.

Table 1. Most probable number of total and faecal coliforms in the sites sampled during the rainy and dry seasons of 2000 and 2001 .

\begin{tabular}{|c|c|c|c|c|c|}
\hline site & Site & 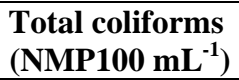 & & $\begin{array}{l}\text { Fecal coliform } \\
\left(\mathrm{NMP100} \mathrm{mL}^{-1}\right)\end{array}$ & \\
\hline year & & 2000 & 2001 & 2000 & 2001 \\
\hline \multirow[t]{18}{*}{ rainy } & IND1 & 40 & 33 & $<2$ & 33 \\
\hline & IND2 & 110 & 50 & 20 & 2 \\
\hline & IND3 & 170 & 21 & 40 & 2 \\
\hline & IND4 & 170 & 220 & 20 & 2 \\
\hline & IND5 & 140 & 220 & $<2$ & 80 \\
\hline & PEI1 & 2800 & 240 & 500 & 26 \\
\hline & PEI2 & 2200 & 240 & 700 & 50 \\
\hline & CAR & 2 & $<2$ & 2 & $<2$ \\
\hline & SBR & 28000 & 200 & 22000 & 200 \\
\hline & PER & 50000 & 800 & 30000 & 170 \\
\hline & SER & 160000 & 160000 & 160000 & 160000 \\
\hline & PIR & 160000 & 1600000 & 50000 & 3400 \\
\hline & IPR & 160000 & 1600000 & 160000 & 1600000 \\
\hline & DOR & 30000 & 24000 & 30000 & 800 \\
\hline & DOL & 500 & 7 & 20 & $<2$ \\
\hline & AML & 140 & 60 & 14 & $<2$ \\
\hline & ACL & 90 & 4 & 19 & $<2$ \\
\hline & CAL & ND & 8 & ND & 4 \\
\hline \multirow[t]{18}{*}{ DRY } & IND1 & 19 & 90 & $<2$ & 11 \\
\hline & IND2 & 19 & 23 & $<2$ & 4 \\
\hline & IND3 & 40 & 14 & $<2$ & 4 \\
\hline & IND4 & 40 & 24 & $<2$ & 4 \\
\hline & IND5 & 40 & 280 & 20 & 80 \\
\hline & PEI1 & 110 & 900 & 80 & 220 \\
\hline & PEI2 & 110 & 500 & 80 & 280 \\
\hline & CAR & $<2$ & 400 & $<2$ & 200 \\
\hline & SBR & 22000 & 200 & 2000 & $<2$ \\
\hline & PER & 7000 & 7000 & 2000 & 1100 \\
\hline & SER & 8000 & 200 & 7000 & $<2$ \\
\hline & PIR & 160000 & 160000 & 9000 & 9000 \\
\hline & IPR & 160000 & 160000 & 35000 & 160000 \\
\hline & DOR & 30000 & 3400 & 22000 & 3400 \\
\hline & DOL & 110 & 1600 & 90 & $<2$ \\
\hline & AML & 90 & 80 & 60 & 7 \\
\hline & ACL & 340 & 6 & 330 & $<2$ \\
\hline & CAL & ND & 4 & ND & 4 \\
\hline
\end{tabular}




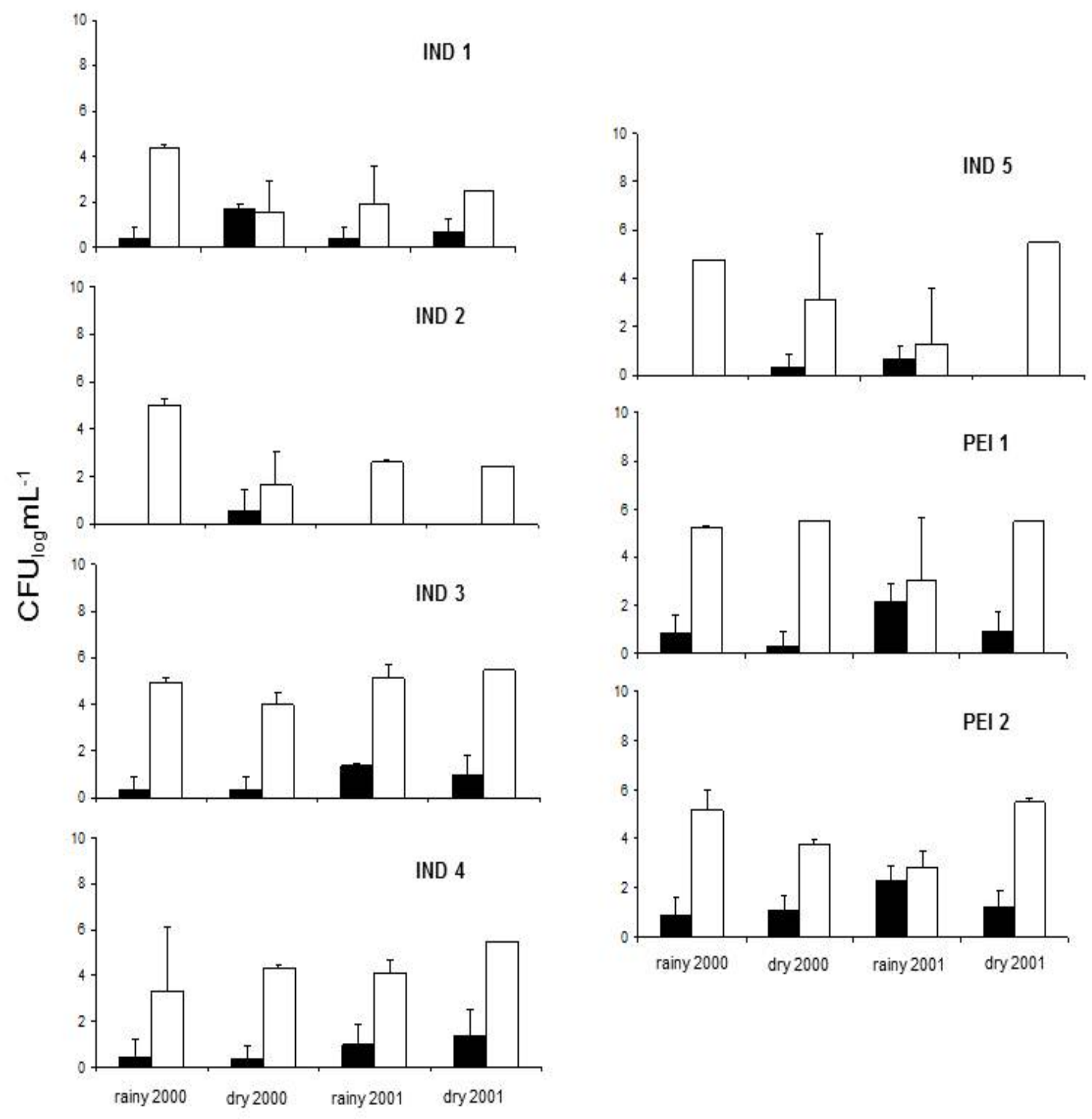

Figure 2. Counts of heterotrophic bacteria (A) and yeasts (B) in the sampled sites in Serra do Cipó during the rainy and dry seasons of 2000 and 2001 (mean $\pm \mathrm{SE}, \mathrm{n}=3$ ). Abbreviations are described in the text. 


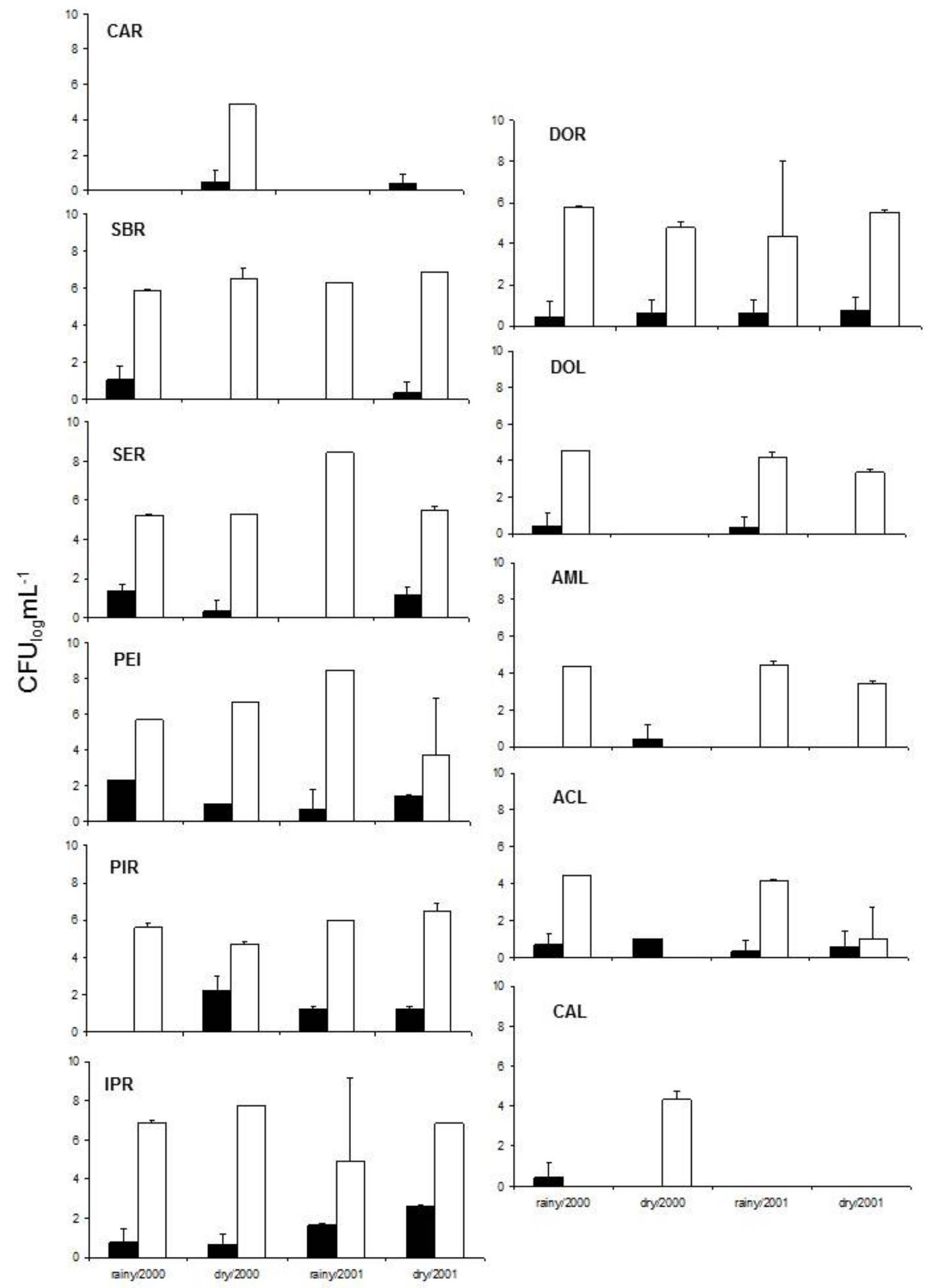

Figure 3. Counts of heterotrophic bacteria $\square$ and yeasts $\boldsymbol{m}$, during the rainy and dry seasons of 2000 and 2001 (means \pm SE, $n=3$ ) in the sample sites in the middle of the Doce River basin. 


\section{Yeast species}

In the present study, we recorded a total of 317 yeast isolates belonging to 21 genera and 48 species, including the colourless algae Prototheca spp. (Table 2). 18 yeast species were identified in the sites sampled at Serra do Cipó. This species belong to the genera Aureobasidium, Candida, Cryptococcus, Debaryomyces, Kloekera, Kodamaea, Metschinikowia, Pichia and Rhodotorula. The highest number of yeast species were found in the Peixe river ( 5 and 8 yeasts species in sites PEI1 and PEI2, respectively) and the species Kloeckera japonica had the highest frequency and the the black yeast Aureobasidium pullulans was prevalent at the sample sites of Serra do Cipó.

In the sampled sites at the middle of the Doce River basin, the rivers had the highest numbers of yeast species. The IPR site presented the highest number of species during the dry season of 2001 with 18 species of yeasts from the 20 species identified in this site during this study. In the lakes, the highest number of species were found during the dry season of 2000 in the ACL ( 9 species). Some yeast species, such as Meyerozyma guilliermondii and Kloekera apis, were isolated from the rivers at the middle of the Doce River basin. The genus with the highest number of species identified was Candida (13 different species). The opportunistic species C. guilliermondii and C. krusei were isolated from the rivers and Candida krusei mainly in the rainy period of 2000. Cryptococcus laurentii, C. luteolus, C. hungaricus and C. albidus were isolated from almost all of the sampled sites. Species of Rhodotorula were isolated at the IPR and PIR sites from the middle of the Doce River basin. The other species isolated in the present study had low counts. The colourless algae Prototheca was isolated at the site IPR, located at the middle of the Doce River basin.

Table 2. The density of yeast species $\left(\mathrm{cfu} \mathrm{ml}^{-1}\right)$ sampled in the rainy and dry seasons of 2000 and 2001. (mean $\pm \mathrm{SE}, \mathrm{n}=3$ ).

\begin{tabular}{|c|c|c|c|c|c|}
\hline \multirow[t]{2}{*}{ Sites } & \multirow[t]{2}{*}{ yeast species } & \multicolumn{4}{|c|}{ period of samples } \\
\hline & & Rainy (2000) & Dry (2000) & Rainy (2001) & Dry (2001) \\
\hline \multirow[t]{2}{*}{ IND1 } & Kodamaea ohmeri & 3.3 & & & \\
\hline & Rhodotorula mucilaginosa & & & 33.3 & \\
\hline IND2 & Aureobasidium pullulans & & & 10.3 & \\
\hline \multirow[t]{3}{*}{ IND3 } & Aureobasidium pullulans & & 23.3 & & \\
\hline & Debaryomyces hansenii & & & & 5 \\
\hline & Kodamaea ohmeri & 3.3 & & & \\
\hline \multirow[t]{7}{*}{ IND4 } & Aureobasidium pullulans & & 10 & & \\
\hline & Candida blankei & & & & 85 \\
\hline & Candida entomophila - like & & & & 5 \\
\hline & Candida melibiosica & & & & 20 \\
\hline & Cryptococcus albidus & & 25 & & 15 \\
\hline & Kodamaea ohmeri & 3.3 & & & \\
\hline & Wickerhamomyces pijperi* & & & 3.3 & \\
\hline \multirow[t]{2}{*}{ IND5 } & Candida palmioleophila* & & & 3.3 & \\
\hline & Candida parapsilosis & & 5 & & \\
\hline \multirow[t]{5}{*}{ PEI1 } & Aureobasidium pullulans & 3.3 & & & 3.3 \\
\hline & Candida guilliermondii & & 70 & & \\
\hline & Cryptococcus luteolus & 3.3 & & & \\
\hline & Kloeckera japonica & & 153 & & \\
\hline & Rhodotorula glutinis & 3.3 & & & \\
\hline \multirow[t]{5}{*}{ PEI2 } & Aureobasidium pullulans & 6.6 & 13.3 & 3.3 & 6.6 \\
\hline & Kloeckera apis & & & & 3.3 \\
\hline & Kloeckera japonica & & 350 & & \\
\hline & Rhodotorula glutinis & & & 6.6 & \\
\hline & Trichosporon montevideense* & 13.3 & & & \\
\hline
\end{tabular}


Table 2. Continuation

\begin{tabular}{|c|c|c|c|c|c|}
\hline \multirow[t]{2}{*}{ Sites } & \multirow[t]{2}{*}{ yeast species } & \multicolumn{4}{|c|}{ period of samples } \\
\hline & & Rainy (2000) & Dry (2000) & Rainy (2001) & Dry (2001) \\
\hline & Cryptococcus laurentii & 6.6 & & & \\
\hline & Metschinikowia reukaufi & 10 & & & \\
\hline & Pichia kluyveri & 6.6 & & & \\
\hline SBR & Saccharomycopsis crataegensis* & 10 & & & \\
\hline \multirow[t]{3}{*}{ PER } & Aureobasidium pullulans & & 3.3 & & \\
\hline & Candida krusei & 3.3 & & & \\
\hline & Meyerozyma guilliermondii & 20 & & & \\
\hline \multirow[t]{10}{*}{ SER } & Aureobasidium pullulans & & & & 10 \\
\hline & Candida ethanolica & & & & 3.3 \\
\hline & Candida krusei & 20 & & & \\
\hline & Candida pararugosa* & & & 3.3 & \\
\hline & Cryptococcus huimpi - like & 16 & & & \\
\hline & Cryptococcus laurentii & & 6.6 & & 10 \\
\hline & Kloeckera apis & 100 & & & \\
\hline & Kluyveromyces marxianus* & 26 & & & \\
\hline & Meyerozyma guilliermondii & & & & 3.3 \\
\hline & Rhodotorula glutinis & 6.6 & & & \\
\hline \multirow[t]{11}{*}{ PIR } & Candida blankii - similar & & 3.3 & & \\
\hline & Candida catenulata & & & & 3.3 \\
\hline & Candida melibiosica & & & & 3.3 \\
\hline & Candida sp1 & & 90 & & \\
\hline & Cryptococcus laurentii & & 20 & & \\
\hline & Cryptococcus luteolus & & 277 & & \\
\hline & Cryptococcus sp. & & 153 & & \\
\hline & Kluyveromyces marxianus & & 13 & & \\
\hline & Pichia kudriazivei* & & 3.3 & & 6.6 \\
\hline & Rhodotorula mucilaginosa & & 6.6 & & \\
\hline & Trichosporon laibachii & & 3.3 & & \\
\hline \multirow[t]{20}{*}{ IPR } & Aureobasidium pullulans & & & & 10 \\
\hline & Candida krusei & 10 & & & 3.3 \\
\hline & Candida palmioleophila* & & & & 66 \\
\hline & Candida parapsilosis & & & & 161 \\
\hline & Candida rugosa & & & 3.3 & \\
\hline & Candida sp2 & & & & 3.3 \\
\hline & Cryptococcus albidus & & & & 6.6 \\
\hline & Debaryomyces hansenii & & & 3.3 & \\
\hline & Galactomyces geotrichum & & & & 6.6 \\
\hline & Issatchenkia scutulata & & & & 3.3 \\
\hline & Kloekera apis & & & & 23.3 \\
\hline & Kodamaea ohmeri & & & & 6.6 \\
\hline & Prototheca zopfii & & 3.3 & & 33.3 \\
\hline & Pseudozyma antarctica & & & 3.3 & 3.3 \\
\hline & Rhodotorula glutinis & & & & 3.3 \\
\hline & Rhodotorula mucilaginosa & & & & 26.6 \\
\hline & Saccharomyces cereviseae & & & & 3.3 \\
\hline & Sympodimycopsis paphiopedili* & & & & 10 \\
\hline & Yarrowia lipolytica* & & & & 13.3 \\
\hline & yeast-like- fungus & & & & 3.3 \\
\hline \multirow[t]{4}{*}{ DOR } & Candida glabrata - like & 6.6 & & & \\
\hline & Candida krusei & 6.6 & & & \\
\hline & Candida parapsilosis & 6.6 & & & \\
\hline & Cryptococcus magnus & & 5 & & \\
\hline
\end{tabular}


Table 2. Continuation

\begin{tabular}{|c|c|c|c|c|c|}
\hline \multirow[t]{2}{*}{ Sites } & \multirow[t]{2}{*}{ yeast species } & \multicolumn{4}{|c|}{ period of samples } \\
\hline & & Rainy (2000) & Dry (2000) & Rainy (2001) & Dry (2001) \\
\hline$\overline{\mathrm{DOL}}$ & Candida parapsilosis & & & 5 & \\
\hline \multirow[t]{2}{*}{ AML } & Aureobasidium pullulans & & 6.6 & & \\
\hline & Cryptococcus hungaricus & & 3.3 & & \\
\hline \multirow[t]{9}{*}{ ACL } & Aureobasidium pullulans & & 6.6 & & \\
\hline & Candida parapsilosis & & & & 12 \\
\hline & Cryptococcus albidus & & & & 3.3 \\
\hline & Cryptococcus hungaricus & & & 5 & \\
\hline & Cryptococcus luteolus & 6.6 & & 5 & \\
\hline & Leucosporidium scottii & & & & 300 \\
\hline & Pseudozyma antarctica & 6.6 & & & \\
\hline & Rhodotorula glutinis & & 190 & & \\
\hline & Rhodotorula mucilaginosa & & 3.3 & & \\
\hline \multirow[t]{3}{*}{ CAL } & Aureobasidium pullulans & 230 & & & \\
\hline & Rhodotorula glutinis & 13 & & & \\
\hline & Trichosporon montevideense* & 36 & & & \\
\hline
\end{tabular}

\section{Statistical analyses}

The results obtained in relation to PERMANOVA didn't indicate significantly differences in relation to the biotic parameter found in the different years, sites and station $(\mathrm{p}>0.05)$. According to the CCA (Figure 4), where the two axes accounted for $70 \%$ of the total variability of the data the first and second axes explained $47 \%$ and $23 \%$ of the total data variability, respectively. The values of total phospurus, total nitrogen, temperature, $\mathrm{pH}$, total and faecal coliforms, nitrite, ammonium and the yeast species Candida krusei, Candida parapsilosis, Candida sp1, Candida catenulada, Metschinikowia reukaufi and Rhodotorula mucilaginosa have a positive correlation. On contrary the values of dissolved oxygen had a negative correlation with the species Aureobasidium pullulans, Candida sp2, Candida pararugosa, Kloekera japonica, Rhodotorula glutinis and Meyerozyma guilliermondii.

Figure 4. Correlation of biotic and abiotic parameters with the two axes of Canonical Correspondence Analyses (CCA). TEMP $=$ temperature, condut $=$ conductivity, $\mathrm{OD}=$ dissolved oxygen, $\mathrm{P}$-total $=$ total phosphorus, $\mathrm{PO} 4$ - orthophosphate, $\mathrm{N}$ - tot $=$ total nitrogen, $\mathrm{NH} 4=$ nitrate, $\mathrm{NO} 3=$ nitrite, $\mathrm{AP}=$ Aureobasidium pullulans, $\mathrm{Cb} 1=$ Candida blankei, $\mathrm{Cb} 2=$ Candida blankeisimilar, $\mathrm{Cc}=$ Candida catenulata, $\mathrm{Cn}=$ Candida entomophila-like, $\mathrm{Ct}=$ Candida ethanolica, $\mathrm{Cg}=$ Candida glabrata-like, $\mathrm{Cu}=$ Candida guilliermondii, $\mathrm{Ck}=$ Candida krusei, $\mathrm{Cm}=$ Candida melibiosica, $\mathrm{Cp}=$ Candida palmioleophila, $\mathrm{Cr}=$ Candida parapsilosis, $\mathrm{Cs}=\quad$ Candida pararugosa, $\mathrm{Cr}=$ Candida rugos $a, \mathrm{C} 1=$ Candida $\mathrm{sp} 1, \mathrm{C} 2=$ Candida $\mathrm{sp} 2, \mathrm{Cra}=$ Cryptococcus albidus, $\mathrm{Crh}=$ Cryptococcus huimpi-like, $\mathrm{Cru}=$ Cryptococcus hungaricus, $\mathrm{Crl}=$ Cryptococcus laurentii, $\mathrm{Crs}=$ Cryptococcus luteolus, $\mathrm{Crm}=$ Cryptococcus magnus, $\mathrm{Cr} 1=$ Cryptococcus sp., Dh=Debaryomyces hansenii, $\mathrm{Gg}=$ Galactomyces geotrichum, Is= Issatchenkia scutulata, $\mathrm{Ka}=$ Kloekera apis, $\mathrm{Kj}=$ Kloekera japonica, $\mathrm{Kp}=$ Kloekera apis, $\mathrm{Km}=$ Kluyveromyces marxianus, $\mathrm{Ko}=$ Kodamaea ohmeri, Ls - Leucosporidium scottii, $\mathrm{Mr}=$ Metschinikowia reukaufi, $\mathrm{Mg}=$ Meyerozyma guilliermondii, $\mathrm{Pk}=$ Pichia kluyveri, $\mathrm{Ku}=$ Pichia kudriazivel, $\mathrm{Pz}=$ Prototheca zopfii, $\mathrm{Pa}=$ Pseudozyma antartica, $\mathrm{Rg}=$ Rhodotorula glutinis, $\mathrm{Rm}=$ Rhodotorula mucilaginos $a, \mathrm{Sc}=$

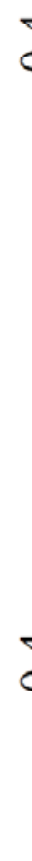

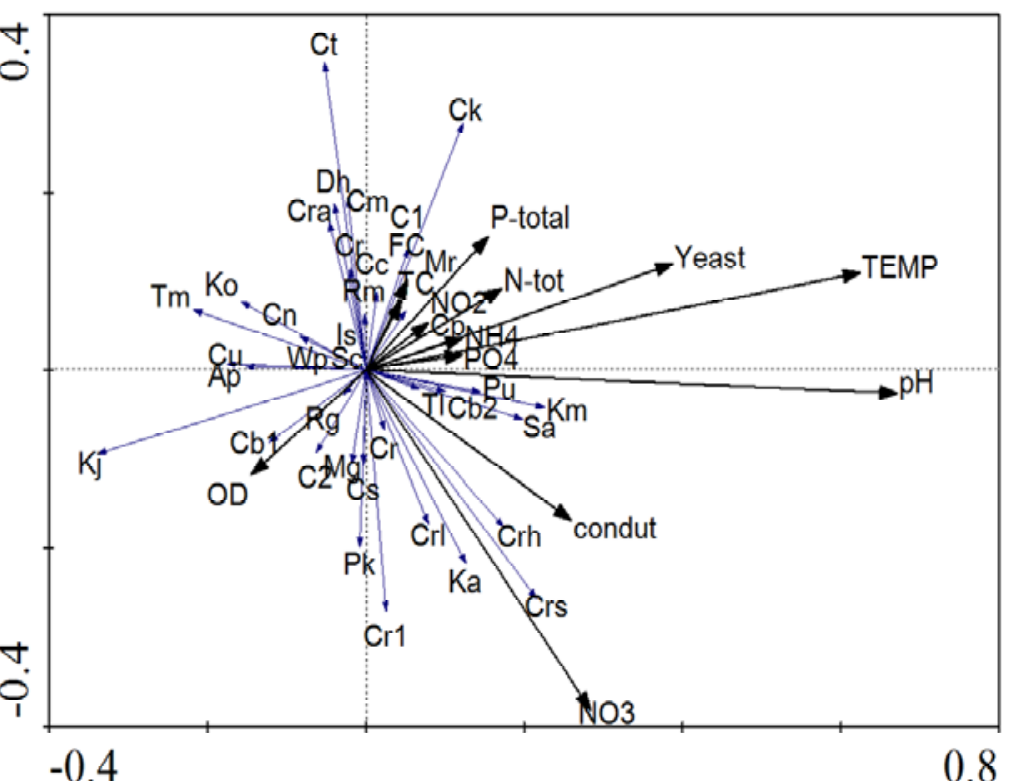

Saccharomyces cereviseae, $\mathrm{Sa}=$ Saccharomycopsis crataegensis, $\mathrm{Sp}=$ Sympodimycopsis paphiopedili, $\mathrm{Tl}=$ Trichosporum laibachii, $\mathrm{Tm}=$ Trichosporum montevideense, $\mathrm{Wp}=$ Wicherhamomyces pijperi, $\mathrm{Yl}=$ Yarrowia 


\section{DISCUSSION}

In the present study, the rivers sampled at the middle of the Doce River basin generally had the highest counts of the microorganisms studied. In regard to the coliform group, which was used to indicate the water quality of the sites sampled, at Serra do Cipó the counts were highest at the sites located outside of the National Park of Serra do Cipó. These sites receive large amounts of organic matter from non-treated effluents from the farms and small towns surround the region (7). The rivers sampled at the middle of the Doce River basin had very high counts of coliform bacteria, and these rivers are under different types of human influences, such as domestic and industrial effluents (22).

The counts of heterotrophic bacteria can be related to the presence of organic matter and, as with the counts of coliform bacteria, heterotrophic bacteria had the highest counts at the rivers in the middle of the Doce River basin, sites known to receive industrial and domestic effluents or waste from cattle raising (22). The same association occurred with the yeast densities, which were high in the sites with high counts of coliform bacteria. Studies done by de Almeida et al. (8) and Brandão et al. (5) found a positive correlation between the counts of yeasts detected after incubation at $37^{\circ} \mathrm{C}$ and the occurrence of E. coli in the Tagus estuary in Portugal and lakes in Southeastern Brazil, respectively.

The variability of microbial counts found in the present study could be explained by the different level of water quality of these environments, as they receive different kinds and levels of pollutants in the form of wastewater, industrial effluents and others. Another explanation could be the atypical rainy season of the two years sampled in the present study, when in the year 2001, rain densities were very low compared to the year 2000 (personal communication).

In the present study, 48 yeast species were isolated and the number of species varied among the sampled sites. Most of the isolated yeast species have been commonly associated with soil, plants and animals, and probably entered the aquatic environment by the rain (20). The number of species increased in sites where the counts of total and faecal coliforms were high. Some species were only isolated at sites with high counts of coliform bacteria and some of these have been reported as opportunistic pathogens. This is the case for Candida krusei, which was isolated only in the rainy season of 2000 at sites with high levels of coliform bacteria (PER, SER, IPR and DOR). According to Sláviková et al. (24) and Sláviková \& Vadkertiová $(25,26,27)$, this species is characteristic of water polluted by wastewater. Candida krusei was detected by Medeiros et al. (19) in a river from the Doce River basin (Piracicaba river). In that same study, they tested this yeast against five antifungal drugs (ketoconazole, fluconazole, itraconazole, terbinafine and amphotericin B), and found that it was resistant to all of them. Candida parapsilosis, another species considered to be an opportunistic pathogen, was isolated mainly in rivers and lakes with low levels of total and faecal coliforms (IND5, DOR and ACL), except for the DOL site. This species was reported by Medeiros et al. (19) in rivers and lakes of the Doce River basin with different levels of pollution. The Cryptococcus species have been isolated from aquatic ecosystems around the world, including oligotrophic, mesotrophic and eutrophicated environments (20). In the present study, these yeasts were isolated from nine of the 18 sites sampled and only four of these sites had the highest counts of total and faecal coliforms (SER, PIR, IPR and DOR).

The yeast-like colourless algae Prototheca was isolated at the sites IPR (P. zopfii). This algae was isolated from other aquatic environments containing high levels of organic matter $(14,23)$ and is considered an emerging pathogen (14). The specie Aureobasidium pullulans were isolated in the majority sampling sites that corroborate the suggestion that this yeastlike species is often isolated from many different types of water $(19,6)$.

In the present studies yeast counts and some species that are considered opportunistic pathogens as Candida krusei and Candida parapsilosis (20) were positive correlated with the parameters that were indicative of the presence of domestic 
wastewater corroborating the propose of Brandão et al (5) that this unicellular fungi can be utilized to indicate freshwater quality.

It is important to consider that the Doce River basin presents different levels of human interactions within the watershed (e.g., mining, siderurgy, and the discharge of untreated sewage), which influence the counts of bacteria of sanitary interest, as well as the counts and species of yeast. In fact, some of these environments could pose a risk to the people that use them for recreation or other uses.

\section{ACKNOWLEDGEMENTS}

This study was supported by the Conselho Nacional de Desenvolvimento Cientifico e Tecnológico-CNPq, Fundação do Amparo a Pesquisa do Estado de Minas Gerais (FAPEMIG), Instituto Estadual de Florestas and the Instituto Brasileiro do Meio Ambiente. We thank the support of Joseline Molozzi for the statistical analyses and Luciano Pataro for the illustration of the sampled sites.

\section{REFERENCES}

1. Altschul, S.; Madden, T.; Schaffer, A.; Zhang, J.; Zhang, Z.; Miller, W.; Lipman, D. (1997). Gapped BLAST and PSI-BLAST: a new generation of protein database search programs. Nucl. Acids Res. 25 (17), 33893402.

2. Anderson, M.J.; Gorley, R.N.; Clarke, K.R. (2008). PERMANOVA + for PRIMER: Guide to software and statistical methods. PRIMER-e, Plymounth.

3. Arvanitidou, M.; Kanellou, K.; Katsouyannopoulos, V.; Tsakris, A. (2002). Diversity of Salmonella spp. and fungi in northern Greek coastal bathing waters and their relation with faecal pollution indicators. Water Res. 36 (20), 5127-5131.

4. Arvanitidou, M.; Kanellou, K.; Vagiona, D.G. (2005). Diversity of Salmonella spp. and fungi in northern Greek rivers and their correlation to fecal pollution indicator. Environ. Res. 99 (2), 278-284.

5. Brandão, L.R.; Medeiros, A.O.; Duarte, M.C.; Babosa, A.C.; Rosa, C.A. (2010). Diversity and antifungal susceptibility of yeasts isolated by multiple-tube fermentation from three freshwater lakes in Brazil. $J$. Water Health. 8 (2), 279-289.

6. Brandão, L.R.; Libkind, Diego; Vaz, A.B.M.; Espírito Santo, L.C.;
Moliné, M..; de García, V; van Broock, M.; Rosa. C.A. 2011. Yeasts from an oligotrophic lake in Patagonia (Argentina): diversity, distribution and synthesis of photoprotective compounds and extracellular enzymes. FEMS Microbiol. Ecol. 75 (1), 1-13.

7. Callisto, M.; Goulart, M.; Medeiros, A.O.; Moreno, P.; Rosa, C.A. (2004). Diversity assessment of benthic macroinvertebrates, yeasts and microbiological indicators along a longitudinal gradient in Serra do Cipó, Brazil. Braz. J. Biol. 64 (4), 743-755.

8. De Almeida, J.M.G.C.F. (2005). Yeasts community survey in the Tagus estuary. FEMS Microb. Ecol. 53 (2), 295-303.

9. Eaton, A.D.; Greenberg, A.E.; Clesceri, L.S.E. (2005). Standard Methods for the Examination of Water and Waste Water. $21^{\text {th }}$ ed. A.P.H.A, Washington. 1600p.

10. Golterman, H.L.; Clymo, R.S.; Ahmstad, A.M. (1978). Methods for physical and chemical analysis of fresh water. Oxford: Blackwell Scientific Publ. Grasshoff, K. (1976). Methods of Seawater Analysis. Verlag Chemie. New York: Weinheim.

11. Hagler A.N. (2006). Yeasts as indicator of environmental quality. In: Rosa C.A, Gábor P (Eds.), Biodiversity and ecophysiology of yeasts. Berlin: Springer, p. 515-532.

12. Hagler, A.N.; Ahearn, D.G. (1987). Ecology of aquatic yeasts. In: Rose, A. H; Harison, J.S. $\left(2^{\mathrm{ed}}\right)$. The yeasts: Biology of yeasts, London: Academic Press. p.181-205.

13. Johnson, B.L.; Richardson, W.B.; Naimo, T.J. (1995). Past, Present, and Future Concepts in Large River Ecology. BioScience. 45 (3), 134-141.

14. Krcmery, V. (2000). Systemic chlorellosis, an emerging infection in humans caused by algae. Int. J. Antimicrob. Agents. 15 (3), 235-237.

15. Kurtzman, C.P.; Fell, J.W. (1998). The yeast: a taxonomic study. 4ed. Amsterdan Elsevier Science B.V.

16. Lachance, M.A.; Bowles, J.M.; Starmer, W.T. \& Barker, J.S. (1999). Kodamaea kakaduensis and Candida tolerans, two new ascomycetous yeast species form Australian Hibiscus flowers. Can. J. Microbiol. 45, (1) $172-177$.

17. Markereth, F.J.H.; Heron, J.; Talling, J.F. (1978). Water analysis: some revised methods for limnologists. Freshwater Biological Association, Cumbria and Dorset, England.

18. Marques, M.M.; Barbosa, F.A.R. (2001). Biological quality of waters from in an impacted tropical watershed (middle Rio Doce basin, southeast Brazil), using benthic macroinvertebrate communities as an indicator. Hydrobiologia. 457, (1-3) 69-76.

19. Medeiros, A. O.; Kohler, L.M.; Hamdan, J.S.; Missagia, B.S.; Barbosa, F.A.R.; Rosa, C.A. (2008). Diversity and antifungal susceptibility of yeasts from tropical freshwater environments in Southeastern Brazil. Water Res. 42, 3921-3929.

20. Nagahama, T. (2006). Yeast biodiversity in freshwater, marine and deepsea environments. In: Rosa CA, Gábor P (Eds.), Biodiversity and ecophysiology of yeasts. Berlin: Springer, pp. 241-262. 
21. Petrucio, M.M.; Barbosa, F.A.R.; Furtado, A.L.S. (2006). Bacterioplankton and phytoplankton production in seven lakes in the Middle Rio Doce basin, south-east Brazil. Limnologica. 36 (3), 192203.

22. Petrucio, M. M.; Medeiros, A.O.; Rosa, C.A.; Barbosa, F.A.R. (2005). Trophic State and Microorganisms Community of Major Sub-Basins of the Middle Rio Doce Basin, Southeast Brazil. Braz. Arch. Biol. Technol. 48 (4), 625-633.

23. Pore, R.S.; Barnett, E.A.; Barness Jr.; W.C.; Walker, J.D. (1983). Prototheca ecology. Mycopathologia. 81 (1), 49-62.

24. Sláviková, E.; Vadkertiová, R.; Koclová-Kratochvilová, A. (1992). Yeasts isolated from artificial lake waters. Can. J. Microbiol. 38 (11), 1206-1209.

25. Sláviková, E.; Vadkertiová, R. (1995). Yeasts and yeasts-like organisms isolated from sil-pond waters. Acta Microbiol. Pol. 44, 191-189.

26. Sláviková, E.; Vadkertiová, R. (1997). Yeast and yeast-like organisms occurring in the river Morava. Fund. Technol. Biotechnol. 35 (4), 293297.

27. Sláviková, E.; Vadkertiová, R. (1997) - Seasonal occurrence of yeasts and yeast-like organisms in the river Danube. Ant. Van Leeuw. 72 (2), $77-80$.

28. Spencer, J. F. T. \& Spencer, D. M. 1997. (Eds) Yeasts in natural and artificial habitat. Springer-Verlag, Berlin.

29. Ter Braak, C.J.F. \& Smilauer, P. (1998). Canoco for Windows v. 45. Micro computer Power. Ithaca. New York.

30. Yarrow, D. (1998). Methods for the isolation and identification of yeasts. In Kurtzman, C. P. \& Fell, J. W. (Ed.). The Yeasts, a Taxonomic Study. $4^{\text {th }}$ ed. Amsterdam, Elsevier, pp. 77-100. 